\title{
UNC13D Gene Mutation
}

National Cancer Institute

\section{Source}

National Cancer Institute. UNC13D Gene Mutation. NCI Thesaurus. Code C158659.

A change in the nucleotide sequence of the UNC13D gene. 